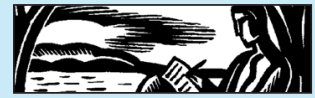

\title{
The Exquisite Ironies of Philippe Lejeune: Nine Auto-Anti-Theses
}

\author{
Julia Watson
}

"We are never really the cause of our life, but we can have the illusion of becoming its author by writing it."

\section{-Philippe Lejeune ("The Autobiography of}

Those Who Do Not Write" 192)

\section{THE AUTOBIOGRAPHICAL PACT IS-OR ISN'T?}

Philippe Lejeune's is unquestionably the name most frequently associated internationally with autobiography studies. In particular, the concept of "the autobiographical pact" (le pacte autobiographique) that he coined and pioneered has shaped the field. ${ }^{1}$ Lejeune clearly set forth its terms. Autobiography is a " $[\mathrm{r}]$ etrospective prose narrative written by a real person concerning his own existence, where the focus is his individual life, in particular the story of his personality" ("Pact" 4). But the clarification I have found most helpful concerns his remarks on the authorial name: "The deep subject of autobiography is the proper name" ("Pact" 20). And, "What defines autobiography for the one who is reading is above all a contract of identity that is sealed by the proper name. And this is true also for the one who is writing the text." ("Pact"19).

Yet, although theorizing the "pact" defined its terms and stakes, some of M. Lejeune's later essays and books have qualified and extended the concept in ways that have an ironically ambivalent edge-an edge I treasure. His brief autobiographical essay "The Autobiographical Pact (bis)" qualifies the methodology of "pact theory" and acknowledges complexities of definition in the baggy practices of life writing. In "(bis)" he wryly references the structuralist and postmodernist suspicion prevailing in the 
eighties about the autobiographical, namely: "What illusion to believe that we can tell the truth, and to believe that each of us has an individual and autonomous existence! ... when it is the text that produces the life" ("(bis)" 131). Lejeune responds pointedly, "Telling the truth about the self, constituting the self as complete subject—it is a fantasy." But he goes on to say, "In spite of the fact that autobiography is impossible, this in no way prevents it from existing ("(bis)” 131-132). Acknowledging that "one does not escape one's self” (“(bis)" 133), he proceeds to write autobiographically on how his study of the relationship between the author's name and the name of the main character led him to confront Serge Doubrovsky's concept of "autofiction" and to acknowledge that the upsurge in novels using the author's name provokes the question, "under what conditions can the proper name of an author be perceived by a reader as "fictitious' or ambiguous?" (135).

For M. Lejeune, the notion of "lying truly" embedded in autofiction is an indeterminacy built into the structure of language. More generally in autobiographical writing, as he suggests in several essays, the I who writes and the I who is written about both are and are not the same. Tellingly, he dismisses "ambiguity" as a refusal to undertake analytical work, and calls for further study of "pragmatics"-importantly, to specify what can be said about the indeterminate (135-136). Thus, while M. Lejeune qualifies the terms of the autobiographical pact in an ironically self-deprecating way in "(bis)," as in my epigraph, the terms of his discussion specify conditions that render it foundational for our field. And the ironic cast of his terms alludes to the paradox at the heart of self-referential writing.

\section{AUTOBIOGRAPHY AND BIOGRAPHY OR AUTO/BIOGRAPHY-TWO SIDES OF THE SAME COIN?}

Indeed, there are sentences tucked away in "Pact" that now resonate for me more than its methodological analysis of Benveniste's semiotic theory and positing of the triadic structure of author-narrator-publisher. Lejeune's assertion that both autobiography and biography as referential genres aim at not just verisimilitude but resemblance to the truth has long informed and enriched our field, notably in the work of Paul John Eakin (Fictions), his important English-language proponent and interpreter. But while both practices share what Lejeune calls, in distinction to fictional forms, "not 'the effect of the real,' but the image of the real," the distinction between the two modes may now seem subsumed under the umbrella of life writing, to the extent that we often insert a slashauto/biography—and see them as two sides of the same coin ("Pact" 22). Ironically, they both are and aren't. 
A few months ago, on rereading the following passage from "Pact", I almost fell off my chair. M. Lejeune states, "[I]n biography resemblance grounds identity, while in autobiography identity grounds resemblance." And "Identity is the real starting point of autobiography, resemblance the impossible horizon of biography" ("Pact" 24). Exactly! What could be clearer, or more insightful?

A further maxim from M. Lejeune is equally telling: "Autobiography is a discourse on the self in which "the question, 'who am I?' is answered by a narrative that tells "how I became who I am" ("(bis)" 124). That is, autobiographical writing narrates the story of a transit to selfhood-a succinct and lucid definition. Despite recent theorizing of the relationality of auto/biographical writing at the gray interface where one bleeds into the other, a fundamental distinction for Lejeune lies in three factors: the differing impulses that motivate the two modes of writing, the kinds of reading they call on audiences to do, and the uses of documentation or evidence in each.

\section{AUTOBIOGRAPHY IS THE SCRIPTING OF A SELF-OR NOT?}

Several other essays in On Autobiography presciently extended the terrain of the autobiographical to collective, visual, and pedagogical contexts a decade before other critics began theorizing them in the United States. A favorite of mine is "The Autobiography of Those Who Do Not Write." Regular conversations with folklorists in my interdisciplinary department, Comparative Studies, taught me how important that essay is for readers outside literary studies who are working on ethnography and oral history in such fields as folklore, education, communications, literacy studies, and gender and ethnic studies.

When I returned to M. Lejeune's essay, as so often happens on rereading them, I noticed something that had previously escaped me: He asserts that "What one tries to capture in writing is the voice" as an autobiographical discourse of a non-writer who belongs to a culture other than the writer's own, but one who does not write becomes "the creature of his ethnographer" ("Do Not Write" 196). For, the ostensible author is inevitably "the product of a transaction between different postures" that are embedded in ideology and social class ("Do Not Write" 196-197). Thus the interplay between "to write or be written" (204) is both dynamic and ironic. The ethnological gap it opens up leads M. Lejeune to a prescient critique that has become central to situating testimony in this century: Writing as an "ethnobiographer" (196) about the "personal" lives of others is an intervention that "at the same time that it is a form of rescue or help ... is an act of violation or voyeurism, a form of abuse of power" 
(210). As a critic of life writing I have come to feel that, whatever I take up for study, M. Lejeune has already considered it-and long ago. This is also good news.

\section{THE AUTOBIOGRAPHY CRITIC LOOKS AT SELF-PORTRAITS LOOKING BACK}

I, like many of us, have long been fascinated by how painted self-portraits seem to simultaneously reveal and conceal so much about the self-perception of the artist making them (since most self-portraitists paint or draw themselves several times). In the nineties, interested in theorizing women's painted and drawn self-portraits, I turned to M. Lejeune's essay, "Looking at a Self-Portrait," which he claimed to have jotted down as hasty diary entries while in various museums. In fact the essay reads like a self-portrait, its observations opening to a hall of mirrors. Perhaps nowhere is his epigrammatic style of piquant observation as pronounced as in this essay, even in translation. For your delectation I cite a few examples, which would not benefit from my further explication.

" $[\mathrm{R}]$ eally, how does it happen that there is no internal sign that allows us to distinguish a self-portrait from a portrait? Perhaps painting is unable to use the "first person' ..." ("Looking" 110)

"A spark. Before a self-portrait, I see again, I saw again (sometimes to the point of hallucination), my own positions in front of the mirror." ("Looking" 114)

"Brush in hand, I reconstruct myself; I fill in the gaps; I surround myself; I restore myself; I put myself back 'in shape' on stage, for others, as another. But it is never very solid, there remains that spark of surprise, a flash of white in the pupil." ("Looking" 114)

"The encounter of the image of the painter can seem anecdotal, on the side of the character, and tautological, on the side of the painting." ("Looking" 116)

"[T]he self-portrait is really, in the religious sense, an apparition. The creative spirit is incarnated in one of the figures of its creation. Looks itself in the face, and stares at itself." ("Looking" 116-117)

"[N] othing is stranger, and more invisible, to you than your own skeleton." ("Looking" 118)

And many more for readers who share the pleasure of such looking, at once reflective and a bit transgressive. Who says there is no poetry in criticism? 


\section{AUTOBIOGRAPHY IS THE STORY OF A SELF- UNLESS IT IS TOTALLY SO}

I am admittedly giving a rather Montaignean inflection to M. Lejeune's pronouncements on autobiography, no doubt influenced by James Olney's concept of the doubled self, which was deeply informed by his study of Montaigne's dialogical essays. But justifiably so, as I discovered on first meeting M. Lejeune at the 1989 Portland, Maine, conference on "The Subject of Autobiography." There, his lecture-in French with translation, although his English is assuredly more proficient than my French-was a highlight of the meeting. It was also the first time that several of us had personally encountered his charmingly quizzical presence. What I remember best is the moment after his lecture when I encountered M. Lejeune himself, in his characteristic powder-blue V-neck sweater, in the hall. In faltering French, I enthusiastically and nervously asked about his assertion that all autobiographical texts are referential. (I am paraphrasing loosely here, given the vagaries of memory): "What about Montaigne? He continuously refers to himself-his readings, events in his life, his thoughts-but the Essays do not fit within the framework you have described."

He smiled and replied in thoughtful detail along the following lines: "Ah, Madame, Montaigne and Stendhal are unique. They have created extensive systems of self-reference that cannot be thought of in the same terms as autobiography." It was a simple response, but illuminating and provocative-both about what was special to a few intellectual projects of self-writing and about the limits of autobiography. While working on Montaigne's Essays I had encountered a similar analysis in Michel Beaujour's Miroirs d'Encre (Poetics of the Literary Self-Portrait), but it had not struck me there with the force of M. Lejeune's observation. Our little conversation clarified that some self-writing breaks through all genre distinctions to cast its own form-the Essays, Stendhal's The Life of Henri Brulard. Perhaps we are seeing more of such projects now, with the "novels" of Karl Ove Knausgaard and the work of some visual-verbal autobiographers?

\section{LEJEUNE IS THE MASTER THEORIST OF AUTOBIOGRAPHY- OR OF DIARY?}

Another lovely irony is that, although in the U.S. M. Lejeune's name remains associated with the notion of the autobiographical pact, he has focused primarily on diary-writing FOR THE LAST QUARTER-CENTURY. And his theorizing of diurnal life writing is equally enabling and insightful. ${ }^{2}$ I first became aware of M. Lejeune's substantial and provocative body of 
work on diary somewhat earlier, while puzzling over the 784 painted and written pages of Charlotte Salomon's Life? Or Theater?, an epic intermedial dramatization of a brief and fragile life. How to think about address and audience in this hasty, furtive, yet resonant project only found years after her death in Auschwitz-Birkenau? In "The Practice of the Private Journal: Chronicle of an Investigation (1986-1998)," an appealingly autobiographical and important essay, Lejeune laid out his research and the method he developed for studying the handwritten diaries of young girls. He observes that every diary, whether published or not, is a "practice" ("Private Journal" 199) that "does not reflect the life as an autobiographical narrative would do" because the writer repeatedly examines her motives and feelings ("Private Journal" 187). Yet however "secret" the diary avowedly may be, it is "motivated by a search for communication, by a will to persuasion" that inevitably postulates a reader ("Private Journal" 192).

M. Lejeune's emphasis on the difference of diaristic writing as openended and future-oriented is a crucial distinction. His turn to theorizing diary was prescient in another way, as it proposed an enabling set of terms for forms of online life inscription, notably blogs, which he explored over a decade ago in his book, Cher écran, and discusses in two essays in the English collection. True, the interactivity of diaristic form and the labile nature of digital self-writing arise from differences in the mediumwriting-pen and paper or word-processor versus the ever-present screen and hyperlinks of the computer or smart-phone. Yet both accrete through regular entries and embed moments of self-reflection within the contexts of everyday life in ways that other scholars are beginning to explore.

With attention to digital media, diary-writing has come front-and-center in life writing. Diary-keeping has been a primary site and practice of women's life writing for centuries, particularly outside centers of power, as North American feminist scholars such as Cynthia Huff, Suzanne Bunkers, Margo Culley, Rebecca Hogan, and Laurie McNeill have long argued, along with their counterparts (in England, Clare Brant, Harriet Blodgett, and Penny Summerfield; in Germany, Gudrun Wedel and Claudia Ulbrich; in the Netherlands, Monica Soeting; in Australia, Kylie Cardell; along with many others). Diary-writing was long sidelined, to the impoverishment of the field-until their and M. Lejeune's outpouring of work (much of which I am still digesting) began recovering and historicizing the field.

\section{THEORIST OR ARCHIVIST-WHICH CAME FIRST, THE CHICKEN OR THE EGG?}

While we often refer to M. Lejeune as a theorist, on returning to his essays I was struck by how deeply their concern is not just theoretical 
engagements with the work of structuralists, post-structuralists, and various critics of autobiography. In fact, extensive archival study buttresses most of his work, particularly that on unpublished or out of print diaries, notably those of girls and women. He writes wryly of his year in the St. Sulpice seminary archive reading seventeenth-century spiritual journals and examining why some "are highly resistant to reading" while those of the Jesuits are "concise and controlled," and reflects on when, where, and why they appeared ("Spiritual" 73). Motivated by the fact that in 1993 "everyday writing remains very much unknown in France" ("Jeune Fille" 141), not least because diaries have been "indicted" by most critics as not "literature," M. Lejeune read ninety-six young girls' diaries, most published locally if at all, that are archived in library, or other public or family collections, the last of which he solicited through calls to radio stations and ads in newspapers-assembling his own archive. In a series of essays he raises trenchant questions about how such diaries may be read and talked about, given that nineteenth-century "diarists were censored both ideologically and aesthetically" ("Jeune Fille" 131). And he concludes his prescient essay "Diaries on the Internet" about his year of online reading in 1999-2000 by posing a question central to our field today, "Why is the book the point of reference? For the past century it has kept diaries in shackles" (316).

At the end of his compelling essay, "Auto-Genesis," M. Lejeune offers a rationale for his passionate archival work: "Asking about the specific practices of a whole genre permits us to establish transversal links between different authors, but also to ask about works that are perhaps less inventive but which reveal basic generic constraints ... [in order to] map our questions onto the terrain of writing" ("Auto-Genesis" 231). Thus the critic's project of theorizing personal writing and the historian's process of laborious work in diverse archives, both formal and informal, are not opposed activities but mutually sustaining acts. That M. Lejeune combines them with his ongoing-often witty or wistfulpersonal reflections on the why and how of such work only enhances the pleasure of reading his essays.

\section{WHAT'S NEXT?-“WALKING BACKWARDS"}

M. Lejeune recently responded to the question "What's next?" on "The Futures of Auto/Biography Studies" issued by the journal $a / b$ : Auto/ Biography Studies by recalling that, when he began working on autobiography in France with a colleague in the sixties, "we felt like pioneers" because autobiography paradoxically both had a long history and, at least in France, "was . . . a genre in the midst of being born" ("Genre" 159). 
Now, he observes, "autobiography has infiltrated everything" and, with globalization, multiple models of the subject have become visible (160). Yet the concept of the pact is enduring, and continues to provoke dialogue and new formulations. Arnaud Schmitt and Stefan Kierkegaard, for example, in theorizing the "real" novels of Karl Ove Knausgaard ("A Real Life" 576), have recently asserted that "every reading contract is a double pact" between "entryway reading and in media (sic) res reading" ("A Real Life" 560-561) that draws readers into an experience of "reciprocity" and the "mirror effect" and generates "a self-narration, not a life narration" ("A Real Life" 573). Thus a younger generation renovates the concepts of both pact and life writing for evolving autobiographical modes.

Although M. Lejeune focused on online diaries when they were a new phenomenon at the millennial turn (Cher écran), he now admits to a sense of "vertigo" about the future. At the same time he asserts the importance of taking up new-model studies of the past by "walking backwards" in three as yet neglected areas: textual "genetics," the nurturing of autobiographical expression in children, and transhistorical study of traditions of life writing ("Genre" 161). Notably, two of these are projects that his most recent books have taken up. As ever a fresh wind blowing, M. Lejeune at eighty continues to offer interventions in our field that stimulate new research even as they reflect its depth and richness.

\section{EVERY AUTOBIOGRAPHY NEEDS A READER- NON-IRONICALLY}

Above all, I am moved by M. Lejeune's life-long dedication to self-referential writing and acts. His projects, from the early L'Autobiographie en France (1971) to the French website "Autopacte" and the journal he founded, $L a$ Faute à Rousseau, Revue de l'autobiographie, attest to the vast and burgeoning production of the autobiographical in France and beyond. Most remarkably, the group he founded meets regularly in Ambérieu-en Bugey (near Lyon), to read, archive, and write to the authors of all the unpublished autobiographical works that are sent to them (to date, over 3,000). ${ }^{3}$ Thus they provide what autobiographical projects of all sorts seek-a reader, someone to engage with and register another's efforts to be heard-in our shared, ongoing project of trying to make sense of our lives even as we live out their contradictions.

As a result M. Lejeune is a magnificent resource-a walking encyclopedia on the myriad forms, media, and practices of the self-referential. He continues to navigate nimbly amid private and more public forms, multiple media, and the weighty claims of autobiographical genres in 
shaping transpersonal forms of consciousness, particularly in France. This mobility is perhaps the best evidence of M. Lejeune's enduring ability to dance on the tightrope of ironic and even contradictory positions and practices that underlie the corpus of life writing in our times.

\section{WORKS CITED}

Beaujour, Michel. Poetics of the Literary Self-Portrait. (Translation of Miroirs d'Encre, Editions du Seuil, 1980. Translator not named.) New York: NYU Press, 1991.

Eakin, Paul John. Fictions in Autobiography. Studies in the Art of Self-Invention. Princeton: Princeton University Press, 1985.

Lejeune, Philippe. "A New Genre in the Making." $a / b$ : Auto/biography Studies 32.2 (Spring 2017): 159-162.

Lejeune, Philippe. "The Autobiographical Pact.” In On Autobiography, 3-30.

Lejeune, Philippe. "The Autobiographical Pact (bis)," In On Autobiography, 119-137.

Lejeune, Philippe. "The Autobiography of Those Who Do Not Write." In On Autobiography, $185-240$.

Lejeune, Philippe."Auto-Genesis: Genetic Studies of Autobiographical Texts.” In On Diary, 213-235.

Lejeune, Philippe."Autopacte” website http://www.autopacte.org.

Lejeune, Philippe. “Cher écran...”Journal personnel, ordinateur, Internet. Paris: Seuil, 2000.

Lejeune, Philippe. "Diaries on the Internet: A Year of Reading." In On Diary, 299-316.

Lejeune, Philippe. "The Journal de 'Jeune Fille' in Nineteenth-Century France.” In On Diary, 129-143.

Lejeune, Philippe. "Looking at a Self-Portrait," In On Autobiography, 109-118.

Lejeune, Philippe. Eds. Jeremy D. Popkin and Julie Rak, translated by Katherine Durnin. On Diary. Honolulu: University of Hawai'i Press, 2009.

Lejeune, Philippe. On Autobiography. Foreword by Paul John Eakin, translated by Katherine O’Leary. Minneapolis: University of Minnesota Press, 1989.

Lejeune, Philippe. "The Practice of the Private Journal: Chronicle of an Investigation (1986-1998),” Eds. Rachael Langford and Russell West, Trans. Russell West. In Marginal Voices, Marginal Forms: Diaries in European Literature and History. Amsterdam: Rodopi, 1999, 185-211. Reprinted in On Diary, 29-48.

Lejeune, Philippe. "Spiritual Journals in France from the Sixteenth to the Eighteenth Centuries." In On Diary, 61-78.

Schmitt, Arnaud, and Stefan Kierkegaard. "Karl Ove Knausgaard's My Struggle: A Real Life in a Novel." a/b: Auto/biography Studies 31.3 (Autumn 2016): 553-579.

\section{ABOUT THE AUTHOR}

Julia Watson is Professor Emerita of Comparative Studies and former Associate Dean of Arts and Sciences at The Ohio State University. Her books with Sidonie Smith include Reading Autobiography: A Guide to Interpreting Life Narratives (2nd expanded edition, 2010) and Life Writing in the Long Run: A Smith and Watson Reader, 2016, http://dx.doi.org/10.3998/mpub.9739969 as well as five collections of essays. Her most recent essays are on women's graphic memoirs and on Patti Smith's Just Kids. 


\section{NOTES}

1 This is theorized in Lejeune's foundational 1975 book. The essay of that name was published in translation by Katherine O'Leary with a foreword by Paul John Eakin in the ground-breaking collection On Autobiography in 1989.

2 In 2009 several of these essays were gathered and published as On Diary for the Biographical Research Center in English translation by Jeremy Popkin and Julie Rak.

3 "Autopacte" 